\title{
Geospatial Assessment of Carbon Sequestration in Oluwa Forest, South-West Nigeria
}

\author{
Makinde, E.O. ${ }^{1, *}$, Ogundeko, M.O. ${ }^{1}$, and Womiloju, A.A. ${ }^{1}$ \\ ${ }^{1}$ Surveying and Geoinformatics Engineering Department, University of Lagos, Lagos, Nigeria \\ Corresponding Author: *eomakinde@unilag.edu.ng
}

\begin{abstract}
The potential of the forest as a natural sink is vast and enormous and has been well documented in several types of research and reports. This project is an attempt at re-emphasizing this potential, by using geospatial technology, to quantify the amount of carbon sequestered by the Oluwa Forest Reserve. Remote sensing methods, specifically supervised image classification augmented with field data, were employed. Landsat imageries of 1984, 1991, 2002, 2010 and 2015 were obtained and the maximum likelihood supervised classification algorithm was used in obtaining the landuse/land cover information for those years. From this, the trend in the landuse was monitored and ascertained. The study revealed two distinct tree species, and subsequently, four forest strata were established. The heights and diameters at breast height of the trees from ten randomly selected $20 \mathrm{~m} \times 20 \mathrm{~m}$ sample points, were measured. The allometric equation of Brown $(1989,1997)$ was used in estimating the above ground and belowground biomass while the Soil Organic Carbon (SOC) was obtained from the laboratory test on the soil samples, taken at $0-15 \mathrm{~cm}$, and $15-30 \mathrm{~cm}$ from the ten sample points using the Walkey Black method. The total above and belowground biomass was obtained to be 162,826.343 Mg/ha and 32,565.269 Mg/ha respectively while the total SOC was $5.7971 \mathrm{Mg} / \mathrm{ha}$. The total carbon sequestered by the forest was estimated to be $358.565 \mathrm{Mg} \mathrm{Ca}$. A multiple regression analysis was carried out and an adjusted $r$-squared value of 0.9809 with an $f$ test significance of -0.000000401 was obtained. This is to find the correlation between the biomass and the dbh, diameter at breast height and the tree heights, $h$.
\end{abstract}

Keywords: Oluwa Forest, carbon sequestration, allometry, tropical rainforest.

\subsection{Introduction}

The industrial revolution, characterized by fossil fuel burning, cement production and land use change, triggered a chain of events which include among others, the depletion of the ozone layer, climate change and global warming (Guirui et al., 2010). These activities continually release greenhouse gases: Carbon dioxide, $\mathrm{CO}_{2}$, Nitrous Oxide, $\mathrm{N}_{2} \mathrm{O}$, methane, $\mathrm{NH}_{4}$ and fluorinated gases (HFC, PFC, SF, etc); into the atmosphere. The predominant of them being $\mathrm{CO}_{2}$, having in the last two centuries, increased by approximately $90 \mathrm{ppm}$ (from $280 \pm 10 \mathrm{ppm}$ in 1800 to $367 \mathrm{ppm}$ in 1999) according to (Prentice et al., 2001). According to Manual of Observatory (2016), the current estimate of the $\mathrm{CO}_{2}$ concentration for 2015 is above $400 \mathrm{ppm}$. The increase thus stands at about $120 \mathrm{ppm}$, an indication of the increase in the level of industrialization and a proof that human emissions and the rate at which $\mathrm{CO}_{2}$ is being released into the atmosphere has not reduced in any way. This increase in $\mathrm{CO}_{2}$ and other greenhouse gases has raised the average temperature of the earth by $1.6^{\circ} \mathrm{F}$ since the beginning of the 20th century.

However, since the 1970s when the global carbon cycle research began, scientists, engineers and policy makers in the field of climate change and reduction of $\mathrm{CO}_{2}$ emissions, are all constantly searching for ways to mitigate this challenge and come up with remedial measures. NASA recently launched an OCO2 (Orbiting Carbon Observatory 2) satellite mission which is able to take up to 1 million measurements a day of how $\mathrm{CO}_{2}$ moves across the globe from which very detailed snapshot of atmospheric $\mathrm{CO}_{2}$ could be created. The purpose is to learn the exact locations of $\mathrm{CO}_{2}$ sources and sinks on regional scales 
globally (NASA, 2016). Despite these efforts, there is no absolute solution at the moment, but deliberately sequestering carbon, especially in forest areas, the practice of which has greatly increased in the past decade, is standing, not just as a stop gap mechanism, but as a major practice in restoring the balance to the pre-anthrogenic era and it may eventually turn out to be, the best way of addressing this issue (Guirui et al., 2010).

Carbon sequestration, therefore, encompasses the various techniques, naturally or otherwise, of removing carbon dioxide from the atmosphere and storing it in other forms. An example includes terrestrial (forests vegetation and soils), ocean and geological carbon sequestration, which are the natural forms of sequestering carbon. There are other advanced concepts which look at novel approaches to chemical, biological or other processes to recycle or reuse the $\mathrm{CO}_{2}$ that is produced in energy systems (USGS, 2009).

A forest ecosystem, as pointed out in Percy et al. (2003) plays a vital role in stabilizing global climate, absorbing from the atmosphere, about a third of the atmospheric carbon and deforestation in the tropics, for instance, contribute about a fifth of the annual emissions (Popo-Ola and Aiyeloja, 2012). Studies into the role of forest biomass as sinks for carbon as a part of global mitigation effort is therefore frequently being carried out (Awad, 2013).

Some of the forest field studies have been carried out to measure the carbon density of vegetation and soils were aggregated to a global scale, assessing carbon stocks and NPP (Prentice et al., 2001). However, few indigenous studies have been carried out including (Jibrin et al., 2014), which concentrated on Kpashimi Forest Reserve in Niger State, but few had zoomed in on measuring the total carbon stock in the Oluwa Forest Reserve area. Ndor and Iorkua (2013), on the other hand focussed on the impact of agricultural land use on carbon sequestration of soil in Lafia, while Momodu et al. (2011) studied the flow of carbon flow pattern in the forest zones of the whole of Nigeria with emphasis on the influence of land use change on the flow. This study would, therefore, serve as both a forerunner and a reference in this area. It would demonstrate the ability of the Oluwa Forest reserve to act as a carbon sink by estimating the amount of carbon it sequestered from the atmosphere on April 9, 2015 when the fieldwork was carried out.

The allometric equation of Brown (1997) is especially useful for live trees and not fallen litter or standing dead trees. Brown's multispecies biomass equations are usually used for highly diverse tropical rainforests especially when specific or local equations with good precision, are absent (Ebuy et al., 2011). Due to these reasons, the equation was adopted in this study. This study assessed and evaluated the amount of carbon sequestered in Oluwa Forest, in South-West Nigeria.

\subsection{Materials and Methods}

\subsection{The Study Area}

The study area, which is the defunct Oluwa Forest Reserve, now known as Ondo Afforestation One, OA1, is one of the Ondo State Afforestation Programme (OSAP) series. It is located on the northwestern part of the Oluwa Forest, in Lisagbede Village, Odigbo LGA in Ondo State. The total area, based on information supplied by the forest office is about 25,000 Hectares, but geospatial assessment reveals it is approximately $24,097.42 \mathrm{Ha}$. Its geographical extent lies approximately between $4^{\circ} 33^{\prime} 50^{\prime \prime}$ E, 6 ${ }^{\circ} 43^{\prime} 50^{\prime \prime} \mathrm{N}$ and $4^{\circ} 38^{\prime} 30^{\prime \prime}$ E, 6 6 59' $8^{\prime \prime} \mathrm{N}$, spanning about $25 \mathrm{~km}$ stretch (See Figure 1).

Osunade (1991) identified the major plant species within the reserve to comprise of Gmelina arborea, Tectona grandis, Milicia excelsa, Afzelia bipindensis, Antiaris africana, Brachystegia nigerica, Lophira alata, Lovoa trichiliodes, Terminalia ivorensis, Terminalia superba, and Triplochiton scleroxylon. However, within the limits of the study area for this research, out of these many species, only the Tectona grandis and the Gmelina arborea are still predominantly present because the natural vegetation became secondary regrowth forests when it was knocked down to accommodate the afforestation programme which was established in 1980. Also, a substantial portion of the forest has either been replaced by annual/perennial crops, or reduced to fallow regrowth which are in various stages of successional forests. 


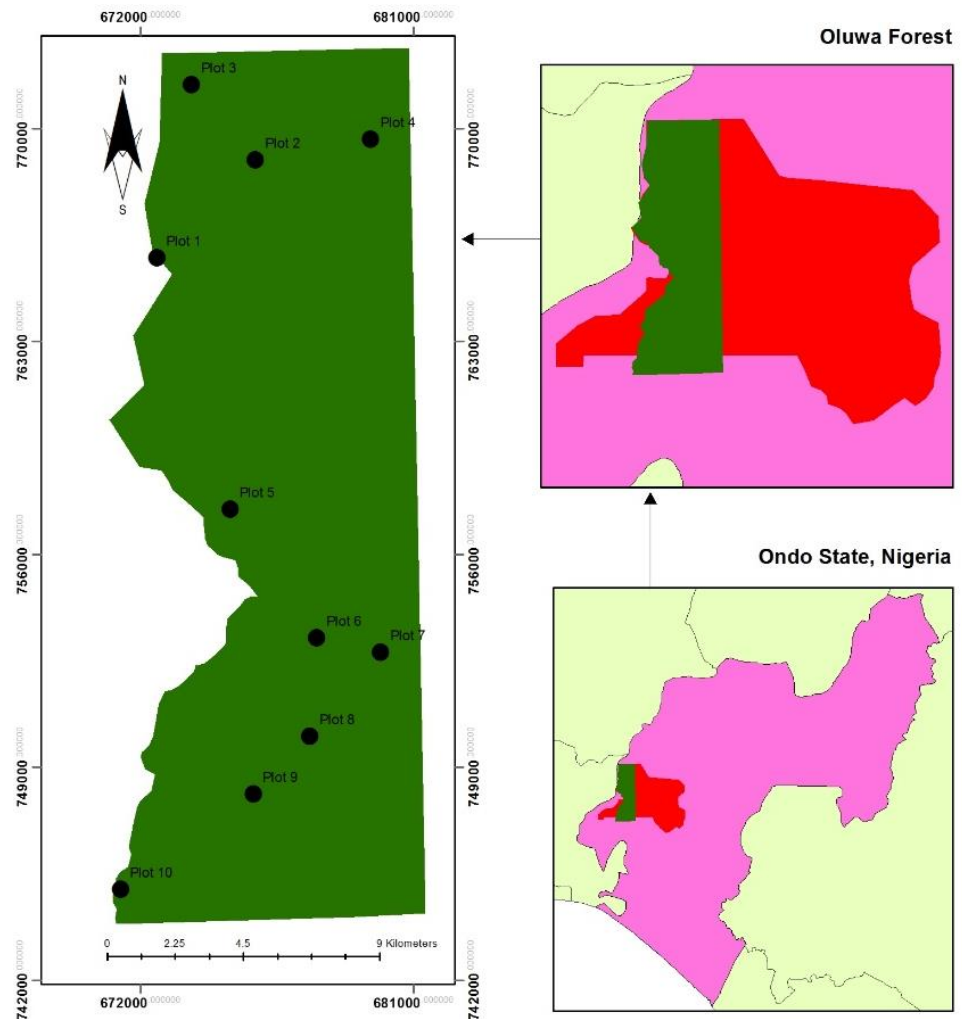

Figure 1: Map of the Location of the study area

The northern part of the forest is the source of the major rivers draining the forest, including the Oluwa, Oni and Ominla rivers. Typical of a rainforest, there are two seasons, the rainy season which is between March and November; and the dry season which occurs between December and February. The range of the annual rainfall is between 1700 and $2200 \mathrm{~mm}$, while the annual mean temperature is $26^{\circ} \mathrm{C}$. The rainforest zone of south-western Nigeria being intensively weathered and composed of basement complex formation areas, the predominant soils in these areas are ferruginous tropical and as a result, based on MBG (2002) (cited in Oseni, et al., 2007), the soils of most tropical rainforests usually have poor nutrients. They are well-drained, mature, red, stony and gravely in the upper parts of the forest. The texture of the topsoil, according to Onyekwelu et al. (2008) and Adeduntan (2009) is mainly sandy loam. The topography ranges from a comparatively lower flat land in the southern and the western parts of the reserve, to a somewhat higher flat land going northward. The elevation, as revealed by the SRTM of the study area, is generally between 68 and $227 \mathrm{~m}$ above mean sea level. The deteriorating reserve is under tremendous economic pressure. The usual practise is to plant four trees for every single tree being harvested, but they are currently being harvested without replanting.

\subsection{Data}

The two types of data used in carrying out this study are: remote sensing data and field data. The remote sensing data are the multi spatio-temporal Landsat Imageries downloaded in 5 years, from the US Geological Survey. The acquisition dates, sensor types and spatial resolution for the Landsat imageries are presented in Table 1.

Table 1: Acquisition dates of the Landsat imageries used

\begin{tabular}{cccc}
\hline Year & Sensor & Spatial Resolution & Acquisition Date \\
\hline 1984 & Landsat 5 TM & $30 \mathrm{~m}$ & December 11 \\
1991 & Landsat 4 TM & $30 \mathrm{~m}$ & January 05 \\
2002 & Landsat 7 ETM+ & $30 \mathrm{~m}$ & January 3rd \\
2010 & Landsat 7 ETM+ & $30 \mathrm{~m}$ & December 11 \\
2015 & Landsat 8 OLI & $30 \mathrm{~m}$ & January 15 \\
\hline
\end{tabular}




\subsection{Fieldwork}

\subsubsection{Pre-Fieldwork}

Before embarking on the fieldwork, an intensive and extensive literature review was conducted. The measurable variables from the field for the allometric equation were enumerated and the suitable instruments were prescribed and acquired. The 2015 Landsat 8 imagery was used in the pre-fieldwork studies by carrying out an unsupervised classification. Initial visits to the study area revealed that the tree species are quite distinct and homogenous in almost all the forest stands. A simple random sampling design was chosen in line with further literature review.

This randomisation of the sample plots was done in ArcMap using the topography, as well as the unsupervised classification result, as a factor and a guide respectively. The location of the ten sampled plots are shown in Figure 2. One of the best and most accurate ways of estimating the carbon sequestered in an area is a combination of remote sensing method and field observation.

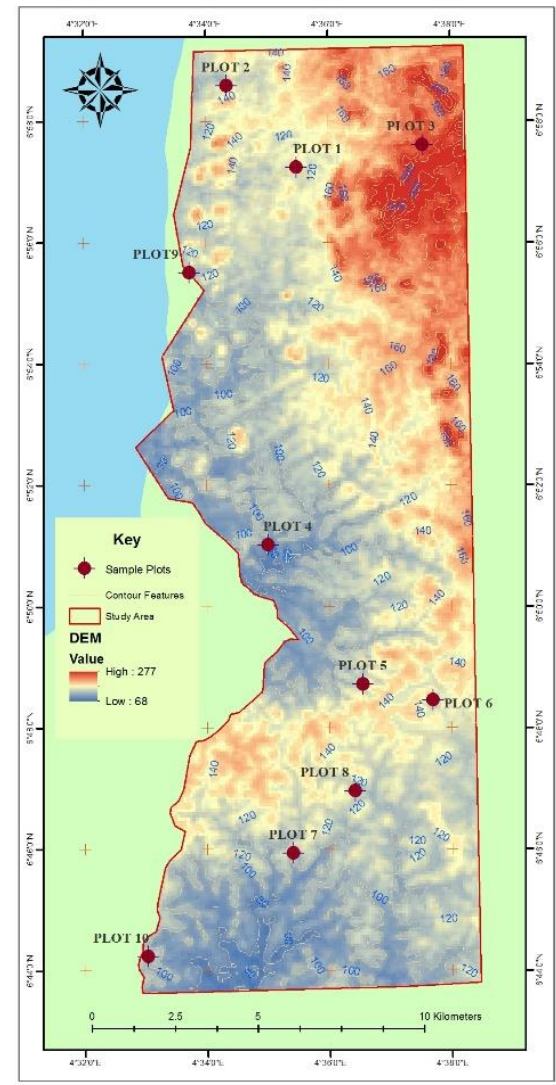

Figure 2: Digital Elevation Map of the study area showing the location of the sample plots

\subsubsection{Sampling Design and Soil Sample Depth}

Sample plots of size $20 \mathrm{~m} \times 20 \mathrm{~m}\left(400 \mathrm{~m}^{2}\right)$, which has been adopted in several literatures were used. During the initial site visits, as noted in the last section, it was discovered that the afforestation programme is structured with close to $100 \%$ homogenous tree species in almost all the forest stands visited. Based on this finding, the locations of the samples were chosen randomly on site, but care was taken to ensure adequate spatial coverage of the study area. A total of ten sample points were identified and are shown in Figure 2.

Soil could be sampled up to $100 \mathrm{~cm}$ depending on the purpose of the study and the samples could be collected at a single core or the soil horizon could be partitioned into depth intervals i.e. split into multiple layers of $0-15 \mathrm{~cm}, 15-30 \mathrm{~cm}, 30-50 \mathrm{~cm}$ and $50-100 \mathrm{~cm}$. However, due the cost of analysing these soil samples, the sampling depth was terminated at the $30 \mathrm{~cm}$ layer. 


\subsubsection{Data Collection}

On the first day of the fieldwork, a reconnaissance survey was first carried out. The purpose was to locate the different forest stands and to design a strategy for carrying out the fieldwork. As with most afforestation programmes and forest reserves, there is a staff dedicated to helping researchers with fieldworks. Here, he is known as the tree finder, and with his help we were able to locate each forest stands.

The first step was to measure out the plot sizes using a $50 \mathrm{~m}$ tape and delineate the area using lines and pegs. The heights and the diameters at breast height of some randomly selected trees were measured next using a laser distometer and a tape respectively. The error in heights measurements, largely due to a lack of broad canopy cover of the tree species, which also did not allow the laser instrument to determine crown heights, is estimated to be a few meters. Due to the unavailability of a tree climber, these measurements could not be cross-checked.

The obtained results were later aggregated and average values both heights and diameters found. Then an inventory of the total number of trees in each plots was carried out.

Finally, soil samples were extracted, at the surface $(0-15 \mathrm{~cm})$ and the subsurface $(15-30 \mathrm{~cm})$ depths for each of the 10 sampling locations for a total of 20 samples. The samples were collected at the middle of each plots. Each sample was labelled appropriately and air-dried for about $48 \mathrm{hrs}$ before being taken to the laboratory for SOC analysis.

\subsubsection{SOC Test}

The Walkley-Black Method of organic carbon content in Soil/Sediment was used to determine the organic carbon in the soil samples. The Chemistry Department laboratory of the University of Lagos Akoka was used for this analysis.

\subsubsection{Allometric Equation}

The allometric equation developed by Brown et al., (1989; 1997) specifically for tropical forests was used in estimating the aboveground biomass of individual trees within the study area. This equation was chosen because firstly, it had been used by other studies such as Udoakpan, (2013) and Abubakar, et al., (2014). Secondly, it is also termed a pan-tropical equation, which makes it applicable to places where specie-specific allometric equations suitable to the forest type of the study area, are not readily available. Lastly, the equation takes as input, the height of the tree and its diameter at breast height, which is the diameter of the tree taken at $1.30 \mathrm{~m}$ above the ground.

\subsubsection{Estimation from Remote Sensing Data}

Due to the nature of the project, no pre-processing nor calibration was carried on any of the images, including 2010 despite its serious striping issue as a result of the Scan Line Correction (SLC) error in the Landsat 4 sensor. This is due to the fact that the pre-processing would have changed the digital numbers (i.e. the brightness values) of the image pixels, thus outputting a different image which in turn would lead to a false representation of the area under study and ultimately give a wrong result. It must however be noted that the striping affected a very negligible part of our study area.

\subsubsection{ERDAS Image Processing}

The downloaded Landsat images were imported into the ERDAS work environment where the applicable bands were first stacked (i.e. false colour composites were created). The $4-3-2$ combination was used for all the Landsat 4, 5 and 7 imageries while the combination band combination $7-5-4$ was used for the Landsat 8 imagery. 
The Area of Interest (AOI) within the study area was extracted and training sites created for each of the land uses/ land covers to be classified. Care was taken to ensure that enough pixels were sampled in order to allow for a very precise classification result with little or no post-classification modifications necessary. An accuracy assessment, which is a measure of the correctness of the classification was carried out as well, using a combination of ground coordinates and randomly generated sample points in ERDAS Imagine.

\subsubsection{Post Classification Processing}

The classification results obtained were first converted from raster to vectors and then imported into ArcMap for further analysis, as well as visualization and presentation. The areas of the different land use and land cover were summarized and the attribute table was opened in MS Excel for statistical analysis and graphical presentation. The area obtained were used in aggregating the biomass for each forest stand by multiplying the total area of each stands with the biomass estimated per hectare of each stand.

\subsubsection{Above and Below Ground Estimation}

Using the Brown (1997) equation:

$$
y=e^{(-3.1141+0.9719 \ln (\mathrm{DBH} \times \mathrm{H})}
$$

Where $y$ is the aboveground biomass in $\mathrm{kg}$; DBH is the diameter at breast height in $\mathrm{cm}$; and $\mathrm{H}$ is the height of tree in $\mathrm{m}$. This gives the above-ground biomass of each tree in a sample plot, which when multiplied by the total number of trees in the plot, gives the total AGB for that plot. Since the species within all the plots with the exception of that of the natural forest, are homogenous, adding the results for all the species gives the respective total AGB for that species. The equation can thus be re-written as:

$$
y_{\text {specie }}=\sum e^{\left(-3.1141+0.9719 \ln \left(\mathrm{DBH}_{\text {specie }} \times \mathrm{H}_{\text {specie }}\right)\right.}
$$

The result obtained was converted to Megagram by multiplying by 0.001 .

Substituting the required variables obtained from each of the sampled plots, the biomass of the living trees was obtained and presented in Table 5.

Aggregates were found and the aboveground and belowground biomass calculated for each of the forest stands when multiplied by the total area covered by each of the forest stand (derived from the supervised classification result for 2015). The result obtained is shown in Table 5 and Figure 6.

\subsubsection{Total Aboveground Biomass (TAGB)}

The total aboveground biomass as shown in equation 2 below is the addition of the biomass for the different forest stands.

$$
\text { Total } A G B=y_{\text {Teak }}+y_{\text {Gmelina }}+y_{\text {Indg }}+y_{\text {Degrad }}
$$

The below ground biomass would thus obtained by:

$$
B G B=0.2 \times A B G
$$

Where 0.2 (or $20 \%$ ) is the assumed proportion of the aboveground biomass commonly used by most literature especially MacDicken (1997).

\subsubsection{SOC Estimation}


The SOC were obtained for the different plant species and the forest strata as follows:

$$
\text { Bulk Density }=\frac{\text { Weighted Sample }}{\text { Volume of Sample }}
$$

For a $10 \mathrm{~g}$ unit sample weight and a $20 \mathrm{~cm}^{3}$ unit sample volume, the unit bulk density would be 0.5 $\mathrm{g} / \mathrm{cm}^{3}$.

For the two depth ranges considered, the depth will remain $15 \mathrm{~cm}$ throughout the calculations. Thus;

$$
\text { Soil Carbon }_{\text {depth }}\left(\frac{\text { specie }}{\text { forest }} \text { stand }\right)=\Sigma T O C_{\text {specie/forest stand }} \times \text { Depth } \times \text { Bulk Density } \times 0.001(M g)
$$

The result obtained are shown in Table 6.

\subsection{Results and Discussion}

\subsection{Plant Species and Composition in OAI}

The predominant plant species and the forest types in OA1 are Tectona grandis and Gmelina arborea and they are as shown in Table 2.

Table 2: Summary of the field measurements

\begin{tabular}{cccccl}
\hline Plot No & Forest type & H $(\mathbf{m})$ & $\mathbf{D}(\mathbf{c m})$ & No of trees & Remarks \\
\hline Plot 1 & Tectona grandis & 20.531 & 91 & 39 & Planted in 1989 \\
Plot 2 & Gmelina arborea & 17.64 & 63.5 & 81 & None \\
Plot 3 & Tectona grandis & 23.708 & 83.5 & 78 & Planted in 1986 \\
Plot 4 & Tectona grandis & 17.278 & 42 & 78 & Planted in 1996 \\
Plot 5 & Natural forest & 16.37 & 168.5 & 208 & Thick and very dense \\
Plot 6 & Tectona grandis & 16.911 & 70 & 22 & None \\
Plot 7 & Tectona grandis & 15.72 & 43 & 30 & Degraded and heavily harvested \\
Plot 8 & Tectona grandis & 22.3 & 40 & 84 & Currently being heavily \\
Plot 9 & Gmelina arborea & 32.453 & 43 & 136 & horvested \\
Plot 10 & Tectona grandis & 23.615 & 57.5 & 42 & None \\
\hline
\end{tabular}

*H is the average heights of the trees; and $\mathrm{D}$ is the average diameters at breast height of the trees.

Aside from the natural forest, the forest stand is composed of two major tree species i.e. Gmelina arborea and Tectona grandis. The natural forest, has always been known to be the most biologically diverse ecosystem in the world (Butler, 2005) and its species composition could not, therefore, be inventoried properly. The summary of the above table into forest strata is as shown in Table 3.

Table 3: The plant species distribution/forest stand and their physical characteristics

\begin{tabular}{ccccc}
\hline Forest Strata & $<\mathbf{4 0} \mathbf{~ c m}$ & $\mathbf{4 0 - 8 0} \mathbf{~ c m}$ & $\mathbf{> 8 0} \mathbf{~ c m}$ & Average tree height $(\mathbf{c m})$ \\
\hline Tectona grandis & 38 & 104 & 113 & 20.72 \\
Gmelina arborea & 88 & 136 & 0 & 25.05 \\
Natural Forest & 2 & 197 & 52 & 16.37 \\
Degraded Forest & 0 & 30 & 0 & 15.72 \\
\hline
\end{tabular}

\subsection{Biomass Estimation}

$$
\begin{aligned}
& \text { Total Above Ground Biomass }=84,177.547+330.521+75,618.541+2,699.73=162,826.343 \mathrm{Mg} \\
& B G B=0.2 \times 162,826.343=32,565.269 \mathrm{Mg}
\end{aligned}
$$

These values are summarized as shown in Table 4 below. 
Table 4: Aboveground and Belowground biomass for the different forest strata

\begin{tabular}{cccc}
\hline Forest Strata & Aboveground Biomass (Mg) & Belowground Biomass (Mg) & Total Biomass (Mg) \\
\hline Tectona grandis & $84,177.547$ & $16,835.5094$ & $101,013.0564$ \\
Gmelina aborea & 330.521 & 66.1042 & 396.6252 \\
Natural Forest & $75,618.541$ & $15,123.7082$ & $90,742.2492$ \\
Degraded Forest & $2,699.734$ & 539.9468 & $3,239.6808$ \\
Total & $\mathbf{1 6 2 , 8 2 6 . 3 4 3}$ & $\mathbf{3 2 , 5 6 5 . 2 6 8 6}$ & $\mathbf{1 9 5 , 3 9 1 . 6 1 1 6}$ \\
\hline
\end{tabular}

\subsubsection{Soil Organic Carbon}

The results of the Soil Organic Carbon (SOC) obtained is shown in Table 5.

Table 5: Summary of the obtained biomass and Soil Organic Carbon for the sample plots

\begin{tabular}{lccc}
\hline \multirow{2}{*}{ Plot No } & Biomass (Mg/ha) & \multicolumn{2}{c}{ TOC (\%) } \\
& & $0-15 \mathrm{~cm}$ & $15-30 \mathrm{~cm}$ \\
\hline Plot 1: Tectona Grandis & 20.71198376 & 6.5 & 9.61 \\
Plot 2: Gmelina aborea & 8.879922948 & 7.1 & 6.48 \\
Plot 3: Tectona Grandis & 20.15302306 & 7.04 & 6.68 \\
Plot 4: Tectona Grandis & 3.896705041 & 5.17 & 8.48 \\
Plot 5: Natural forest & 55.04330045 & 7.79 & 6.35 \\
Plot 6: Tectona Grandis & 10.30065786 & 7.39 & 8.96 \\
Plot 7: Tectona Grandis & 3.721121655 & 6.6 & 8.21 \\
Plot 8: Tectona Grandis & 4.541584165 & 5.91 & 9.49 \\
Plot 9: Gmelina Aborea & 7.527144129 & 2.64 & 6.77 \\
Plot 10: Tectona Grandis & 9.721860488 & 6.4 & 7.39 \\
\hline
\end{tabular}

Table 6. Summary of Soil Organic Carbon for the different forest strata

\begin{tabular}{lcc}
\hline \multirow{2}{*}{ Forest Strata } & \multicolumn{2}{c}{ SOC (Mg) } \\
& $\mathbf{0}-\mathbf{1 5} \mathbf{~ c m}$ & $\mathbf{1 5}-\mathbf{3 0} \mathbf{~ c m}$ \\
\hline Tectona grandis & 0.00028808 & 3.86129 \\
\hline Gmelina aborea & 0.00007305 & 0.02175 \\
\hline Natural Forest & 0.000058425 & 1.4799 \\
\hline Degraded Forest & 0.0000495 & 0.4341 \\
\hline Total & $\mathbf{0 . 0 0 0 4 6 9 0 5 5}$ & $\mathbf{5 . 7 9 7 0 4}$ \\
\hline
\end{tabular}

\subsubsection{Carbon stock estimation}

The sum total of all the biomass obtained from the three pools considered which are AGB, BGB and SOC was calculated as shown below and the carbon stock was obtained using the equation 6 below.

Carbon density in standing tree $=$ Total Biomass $\times \%$ Carbon

Carbon density in standing trees $(\mathrm{AGB})=162,826.343 \mathrm{Mg} \times 0.5=81,413.1715 \mathrm{Mg}$

Carbon density below ground $=(\mathrm{BGB}) 0.5+\mathrm{SOC}=(32,565.2686) 0.5+5.7970=16,288.431 \mathrm{Mg}$

Total Carbon Stock $=$ AGB Carbon Stock in trees + TBGB Carbon Stock $=81,413.172 \mathrm{Mg}+16,288.431 \mathrm{Mg}$

$$
=97,701.603 \mathrm{Mg}
$$




\subsubsection{Carbon Sequestered}

The total carbon stock was obtained using the equation 7 below.

Total Carbon Stock $=0.5 \times$ Total Biomass

The total carbon sequestered by the forest is given by the equation 8 below:

$\mathrm{CO}_{2}=$ Total Carbon Stock $\times 3.67$

$\mathrm{CO}_{2}=97,701.603 \times 3.67=358,564.88301=358.565 \mathrm{Gg} \mathrm{C}$

\subsection{Supervised Classification of the Landsat Imageries}

The maximum likelihood algorithm was used in carrying out the classification. The results obtained are summarized as shown in Table 7 and Figure 3.

Table 7: Land use/Land cover distribution between 1984 and 2015

\begin{tabular}{|c|c|c|c|c|c|c|c|c|c|c|}
\hline \multirow{2}{*}{$\begin{array}{l}\text { Landuse/ Land } \\
\text { cover }\end{array}$} & \multicolumn{2}{|c|}{1984} & \multicolumn{2}{|c|}{1991} & \multicolumn{2}{|l|}{2002} & \multicolumn{2}{|c|}{2010} & \multicolumn{2}{|c|}{2015} \\
\hline & Area & $\begin{array}{c}\% \\
\text { Cover }\end{array}$ & Area & $\begin{array}{c}\% \\
\text { Cover }\end{array}$ & Area & $\begin{array}{c}\% \\
\text { Cover }\end{array}$ & Area & $\begin{array}{c}\% \\
\text { Cover }\end{array}$ & Area & $\begin{array}{c}\% \\
\text { Cover }\end{array}$ \\
\hline $\begin{array}{l}\text { Built Up/bare } \\
\text { ground }\end{array}$ & 25000347.5 & 10.33 & 12079904.5 & 4.99 & 7400277.7 & 3.06 & 1869637.5 & 0.77 & 4328775 & 1.789047 \\
\hline Gmelina arborea & 24791368.5 & 10.24 & 91618465.5 & 37.86 & 109387114.2 & 45.19 & 49351612.5 & 20.40 & 1160662.5 & 0.48 \\
\hline Natural Forest & 162073511 & 66.98 & 84552650.5 & 34.94 & 59487916.7 & 24.58 & 74056387.5 & 30.61 & 139551075 & 57.68 \\
\hline Tectona grandis & 30121955.5 & 12.45 & 53717977 & 22.20 & 65780974.7 & 27.18 & 116521762.5 & 48.16 & 57834112.5 & 23.90 \\
\hline Wetland & - & - & - & - & - & - & 159975 & 0.07 & 450 & 0.00 \\
\hline Deforested & - & - & - & - & - & - & - & - & 39084750 & 16.15 \\
\hline Grand Total & 241987182.5 & 100.00 & 241968997.5 & 100.00 & 242056283.3 & 100.00 & 241959375 & 100.00 & 241959825 & 100.00 \\
\hline
\end{tabular}

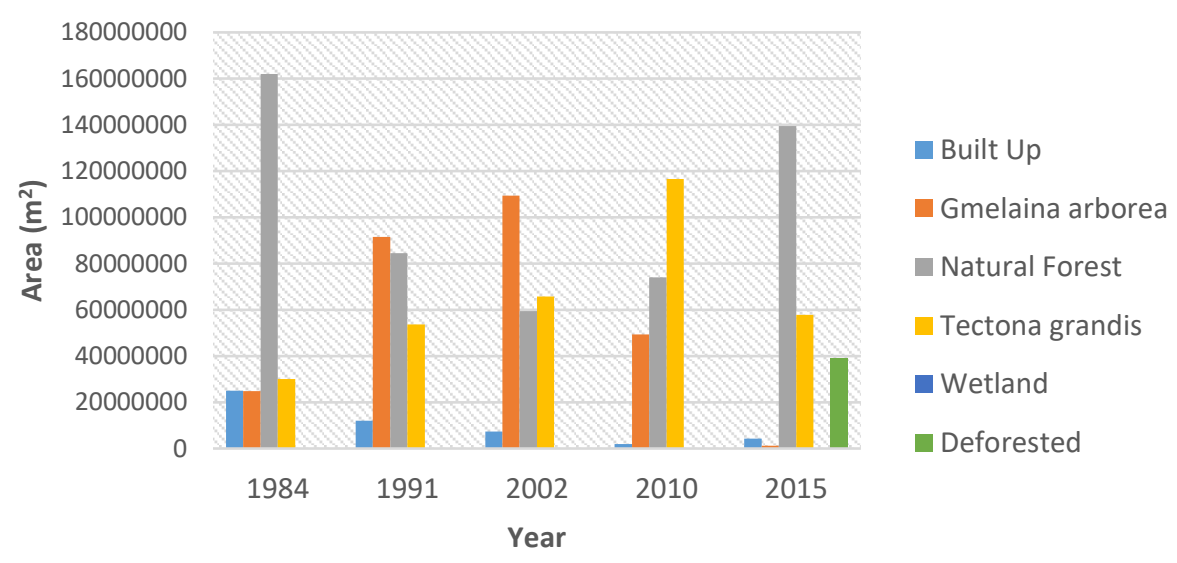

Figure 3. Areal Distribution of Land use/Land Cover between 1984 and 2015

\subsubsection{Accuracy Assessment}

The overall accuracy for the 2015 classification was obtained as $89.17 \%$ while the overall kappa coefficient was 0.8223 . The accuracy totals for the same year is shown in Table 8 . 
Table 8: The accuracy totals

\begin{tabular}{lccccc}
\hline Class Name & $\begin{array}{c}\text { Reference } \\
\text { Totals }\end{array}$ & $\begin{array}{c}\text { Classified } \\
\text { Totals }\end{array}$ & $\begin{array}{c}\text { Number } \\
\text { Correct }\end{array}$ & $\begin{array}{c}\text { Producers } \\
\text { Accuracy }\end{array}$ & $\begin{array}{c}\text { Users } \\
\text { Accuracy }\end{array}$ \\
\hline Unclassified & 0 & 0 & 0 & - & - \\
Mountain Patch & 1 & 2 & 1 & $100.00 \%$ & $50.00 \%$ \\
Water & 0 & 0 & 0 & - & - \\
Bare ground & 2 & 1 & 1 & $50.00 \%$ & $100.00 \%$ \\
Built up & 0 & 0 & 0 & - & - \\
Gmelina arborea & 11 & 4 & 4 & $36.36 \%$ & $100.00 \%$ \\
Deforested & 15 & 15 & 13 & $86.67 \%$ & $86.67 \%$ \\
Tectona Grandis & 27 & 25 & 25 & $92.59 \%$ & $100.00 \%$ \\
Natural Forest & 64 & 73 & 63 & $98.44 \%$ & $86.30 \%$ \\
Totals & $\mathbf{1 2 0}$ & $\mathbf{1 2 0}$ & $\mathbf{1 0 7}$ & & \\
\hline
\end{tabular}

\subsection{Regression Analysis and Prediction}

Multiple regression analysis of the biomass with the tree heights and the diameter at breast height was carried out in Excel and an adjusted R square of 0.980876 with a significance of 0.0000004013 was obtained. The model developed is given as:

$$
y=0.077411 H+0.105236 D-5.23038
$$

Where $\mathrm{H}$ and $\mathrm{D}$ are respectively the tree height and its diameter at breast height. And $\mathrm{y}$ is the biomass.

\subsection{Maps}

The following are the resulting maps created in the study:

\subsubsection{Supervised Classification Maps}

The time series supervised classification maps from 1984 - 2015 showing the transition and change in the land use and land cover is shown in Figure 4.

\subsubsection{Biomass Distribution Maps}

The biomass distribution map was obtained by the Inverted Distance Weight (IDW) interpolation method using ArcGIS. This is shown in Figure 5.

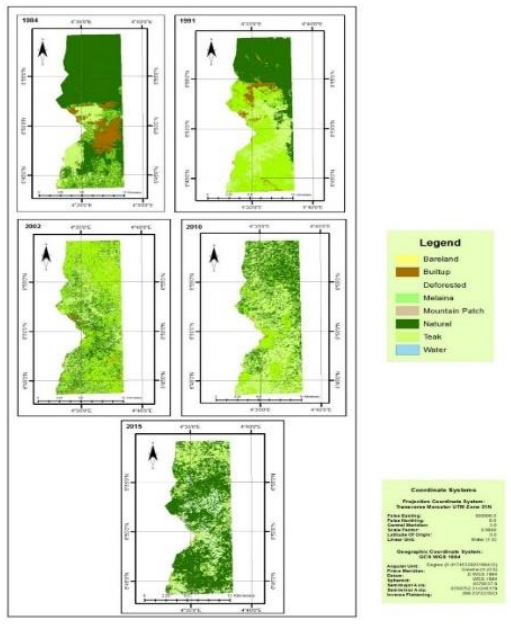

Figure 4: Supervised Classification of the Area for the years under study

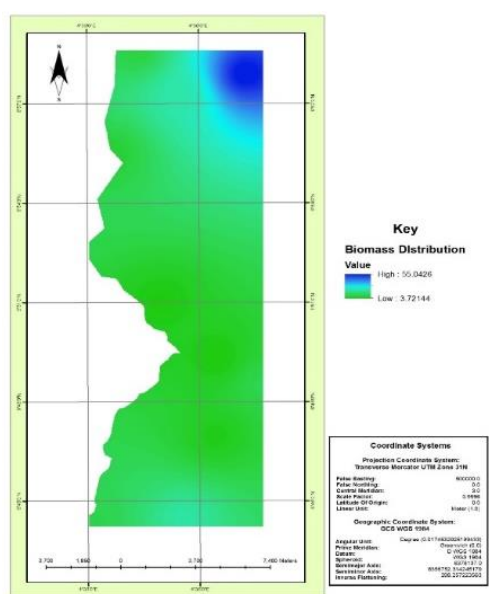

Figure 5: Biomass Distribution map 


\subsection{Discussion}

The emphasis of this study is to estimate the amount of carbon stored within the chosen parts of the Oluwa Forest. Although higher resolution imageries especially LiDAR, would provide a better biomass estimation as it is able to overcome the data saturation which generates large uncertainty for sites with high biomass density, whereas Landsat is unable to deal with this challenge (Lu et al., 2012). However, several studies had demonstrated the capability of Landsat data in estimating biomass to a reasonable extent (Deering and Haas, 1980; Hall et al., 2006; Zhu, 2014). It has even been suggested that sensors such as ADAR and AVIRIS, with higher spectral and spatial resolutions does not considerably improve the prediction of the attributes of forest stands (Labrecque et al., 2006).

\subsubsection{Plant Species Composition}

In the plant species composition analysis, plot sampling as opposed to quadrat sampling, which was also supported in several literatures, was used. This did not permit the calculation of the biodiversity of the woody plant species within the plots (Omodanisi, 2011; Cohn, 2011). However, plot sampling is the generally accepted method of sampling for biomass estimation. This study found out that due to the afforestation programme, the predominant species identified were Tectona grandis and Gmelina arborea. However, there is still a significant portion of the original natural forest left. Out of the ten sample plots, seven consist of Tectona grandis plantations, two are Gmelina arborea while one is a natural forest. The nine plots made up of the Tectona grandis and Gmelina arborea trees, showed more or less the same trend, a homogenous forest stand which includes only the trees of either of these two species. The only sample plot where a diverse tree species was observed was plot 5 , which was in the natural forest. The diameter at breast height $(\mathrm{dbh})$ of the smaller trees in the ten sample plots ranged from 13 to $92 \mathrm{~cm}$, while the dhb of the bigger trees ranged from 47 to $245 \mathrm{~cm}$. The tree heights on the other hand ranged from 3.59 to $15.02 \mathrm{~m}$ and 9.31 to $18.25 \mathrm{~m}$ for the smaller and bigger trees respectively. The tallest tree was found in plot 3 which is a 1986 Tectona grandis plantation, but the broadest tree was observed in plot 5, in the natural forest. Also within the $400 \mathrm{~m}^{2}$ plot sample of the natural forest, up to 15 different plant species was observed, but most of them could not be properly identified. This is usually the norm with most tropical rainforests worldwide, they have the most diversified plants species of the different forest types (SCBD, 2010). This agrees with Akinrinola et al. (2014) and the report of (USAID, 2008). It also confirms the findings of Onyekwelu et al. (2006) that Nigeria's rainforests have a high plant diversity with over 560 tree species, at a range of about 30 to 70 species per hectare.

\subsubsection{Above and Below Ground Biomass}

The dry biomass of the average tree in each plots was estimated to be between 0.967 and 14.307 $\mathrm{Mg} /$ tree, with an average of $3.756 \mathrm{Mg} /$ tree. The lowest biomass was obtained in plot 7, which is the heavily harvested or degraded forest. This plot also has the lowest dbh. The highest biomass was obtained in plot 5 where coincidentally the highest dbh of the trees was recorded. This thus confirms the assertion of (Brown, 1997) that biomass per tree increases geometrically with increasing tree diameter. This study found out that tall trees do not translate to large biomass. As can be seen, the plots with the top tree heights are 9,3 and 10 with corresponding biomass estimates of 1.96, 5.28 and 2.53 $\mathrm{Mg}$ while the plots with the top three dbh are 5, 1 and 3 and have corresponding biomass of 14.31, 5.38 $\mathrm{Mg}$ and $5.24 \mathrm{Mg}$, which are also the top three biomass density. This is an indication that dbh have a stronger influence on biomass than tree heights (Cohn, 2011). However, these results could also be explained due to the age of these plantations as their average age is about $28 \mathrm{yrs}$.

In this study, the biomass estimates for other possible carbon pools were not carried out for two reasons. First, most biomass estimation to date usually focused on the aboveground tree components which account for the greatest fraction of total biomass. Secondly, the methods for these other components are not as straightforward as that of the aboveground and they pose many logistical problems (Brown, 1997). 


\subsubsection{Soil Organic Carbon}

The Walkey-Black method of estimating the organic carbon underestimate the concentration of organic carbon, as against the dry combustion method which overestimate these concentrations (Sato et al., 2014). It is nonetheless the standard method of SOC determination against which other methods are compared, be it wet or dry (Schumacher, 2002). It is on this background that this method was used in this study.

It was found out that at $0-15 \mathrm{~cm}$, the SOC carbon ranged from $2.64 \%$ to $7.79 \%$ while at $15-30 \mathrm{~cm}$, the range of the organic carbon obtained was $6.35 \%$ to $9.61 \%$. The highest SOC was obtained at Plot 1 which happened to be a controlled plot usually used by various researchers for different studies on the forest. Aside from plots 2, 3 and 5 where the SOC contents reduced with reducing depths which is in agreement with (Gibson et al., 2002), but contrary to the general observation that SOC increased with depths (Batjes, 2001). High SOC contents were also observed in plots which are either currently undergoing serious harvest or are heavily degraded. This agrees with the findings of Lal et al. (1999) that degraded areas have a high capability of sequestering carbon in the soil. However, these findings are contrary to those observed by (Oseni et al., 2007). They obtained SOC values much lower than those obtained in this study in both the natural forest as well as their Gmelina plantation. Variations in soil types, land use and land management practices, rainfall and temperature greatly influence the vertical distribution of SOC (Gibson et al., 2002).

The Total Soil Organic Carbon (TOC) of $5.797 \mathrm{Mg}$ is significantly lower than the aboveground carbon density of $81,413.172 \mathrm{Mg}$. Since the belowground biomass was obtained using the conversion factor suggested by most studies, it is therefore much lower than the aboveground carbon stock. This disagrees with the findings of (Fonseca et al., 2011) that the soil is the main carbon sink and they obtained a soil carbon estimate that is slightly higher than the aboveground carbon stock. It however disagrees with the works of (Doetterl et al., 2015) which inferred that the aboveground biomass, especially in areas with larger tree height, which translates to a larger aboveground carbon stock, is usually higher than the belowground carbon stock. Also, the levels of carbon in soils is modest in tropical forests compared with other biomes (Gorte, 2009). Fonseca et al. (2011) obtained a higher estimate of soil carbon than aboveground biomass because they considered other pools such as roots, and herbaceous vegetation. Jibrin et al. (2014) likewise obtained a similar result. Again, they considered other pools not taken into consideration in this study and the bulk density of the soil samples was determined from oven-dried core samples.

\subsubsection{Total Carbon Stock}

The total carbon stock of $97,702 \mathrm{Mg}$ obtained in this study is however significantly higher than the average total carbon stocks of 54 ton/acre (approx. $121.052 \mathrm{Mg} / \mathrm{ha}$ ) for tropical forests posited by Gorte (2009). It is however comparable to the result obtained by Abubakar et al. (2014), although they adopted a carbon content of $45 \%$ instead of the $50 \%$ used in this study. This is a serious indication, that in spite of the deforestation currently experienced in the forest, it has enormous carbon sequestration potential. The capacity of the Oluwa Forest to sequester approximately $358.565 \mathrm{Gg}$ of carbon dioxide is comparable to the mean carbon stock values obtained by (Jibrin et al., 2014), but it is lower than those reported for tropical forests in South and Southeast Asia (as cited in Odiwe et al., 2012). If the age of the forest stands were to be taken into considerations, these values cannot be compared to those obtained by (Bohre et al., 2013). They obtained a mere $1295.14 \mathrm{t} / \mathrm{Ha}$ of $\mathrm{CO}_{2}$ for 19 years Tectona grandis forest stand, whereas the average age of the forest stands in this study is 25 years. The disparity might also be due to the spatial extents of the forest areas in this study.

However, there is the need to be cautious when comparing these results as differences in variables such as climate, forest types, site types, forest management systems, age of forest, soil characteristics, species composition, methodology and the allometric equation used greatly influence the results obtained leading to acute variations (Masera et al., 2003; Chave et al., 2005, Mani and Parthasarathy, 2007; as cited in (Odiwe et al., 2012)). 


\subsection{Conclusions}

The findings of this study demonstrates the capacity of the forest ecosystem to significantly sequester carbon. There is heavy deforestation and uncontrolled logging currently going on within the forest as indicated by the accelerated increase in the area of the natural forest. This is an indication that the forest reserve need to be protected. With proper forest management practice, the Oluwa forest would greatly influence the carbon balance within the Nigerian atmosphere.

The carbon stocks obtained in this study could be used as a baseline and for future monitoring or modelling of biomass and carbon within the forest.

\section{Acknowledgements}

We wish to sincerely acknowledge everyone who contributed to the success of this study. Worthy of mention are: Dr. (Mrs.) E.O. Makinde, for her immense contribution and micro-level supervision; Womiloju Ahmed for the enthusiasm shown in seeing that this study is completed in record time; Justice $\&$ Mrs. O. Onafowokan for their colossal contributions which made this study a reality and Mr. Ojefini, the Deputy Project Manager at the Ondo State Afforestation Programme who ensured that we had a hitch-free fieldwork by providing us with the necessary background information as well as a comfortable accommodation. Thank you all.

\section{References}

Abubakar, A., Abdulkadir, A., Jibrin, A., and Abubakar, R. B. (2014). An Appraisal of Forest Degradation and Carbon Sequestration of Effan Forest Reserve in Kwara State. Journal of Geography and Earth Sciences, 2(1), 149-163.

Adeduntan, S.A. (2009). "Diversity and abundance of soil mesofauna and microbial population in South-Western Nigeria, African Journal of Pant Science, Vol. 3 No 9, pp. 210-216.

Akinrinola, F. S., Darvell, L. I., Jones, J. M., Williams, A., \& Fuwape, J. A. (2014). Characterization of selected Nigerian biomass for combustion and pyrolysis applications. Energy and Fuels, 28(6), 38213832. http://doi.org/10.1021/ef500278e

Awad M. (2013) The Application of Remote Sensing to Climate Change in Lebanon. A Paper Delivered at the United Nations/Indonesia International Conference on Integrated Space Technology Applications to Climate Change.

Batjes, N. H. (2001). Options for increasing carbon sequestration in West African soils: an exploratory study with special focus on Senegal. Land Degradation \& Development, 1(12), 131-142. Retrieved from http://dx.doi.org/10.1002/ldr.44

Bohre, P., Chaubey, O. P., \& Singhal, P. K. (2013). Biomass Accumulation and Carbon Sequestration in Tectona grandis, 5(3).

Brown S. (1997). Estimating Biomass and Biomass Change of Tropical Forests. A Primer No.134. FAO. Forest Resources Assessment Publication: Roma; 55.

Brown S., Gillespie A.R., Lugo A.E. (1989). Biomass Estimation Methods for Tropical Forests with Applications to Forest Inventory Data. Forest Science 35: 881-902.

Butler, R. A. (2005). Mongabay.com. World deforestation rates and forest cover statistics, 2000- 2005, [updated to correct FAO change in data]. http://news.mongabay.com/2005/1115-forests.html; last accessed February 2007.

Cohn, J. (2011). Variation in above ground biomass in Nyungwe Forest, Rwanda. 
Deering, D. W., \& Haas, R. H. (1980). Using Landsat Digital Data for Estimating Green Biomass. NASA Technical Memorandum 80727.

Doetterl, S., Kearsley, E., Bauters, M., \& Hufkens, K. (2015). Aboveground vs. Belowground Carbon Stocks in African Tropical Lowland Rainforest: Drivers and Implications. Plos One, (November 24), 1-14. http://doi.org/10.1371/journal.pone.0143209

Ebuy, J., Lokombe, J. P., Ponette, Q., Sonwa, D., \& Picard, N. (2011). Allometric equation for predicting aboveground biomass of three tree species. Journal of Tropical Forest Science, 23(2), 125132.

Fonseca, W., Alice, F. E., \& Rey-benayas, J. M. (2011). Carbon accumulation in aboveground and belowground biomass and soil of different age native forest plantations in the humid tropical lowlands of Costa Rica. New Forests. http://doi.org/10.1007/s11056-011-9273-9

Gibson, T. S., Chan, K. Y., Sharma, G., \& Shearman, R. (2002). Soil Carbon Sequestration Utilising Recycled Organics. Resource NSW.

Gorte, R. W. (2009). Carbon Sequestration in Forests. Congressional Research Service, RL31432(August), 1-26.

Guirui, Y. U., Xuanran, L. I., Qiufeng, W., \& Shenggong, L. I. (2010). Carbon Storage and Its Spatial Pattern of Terrestrial Ecosystem in China, 1, 97-109. http://doi.org/10.3969/j.issn.1674764x.2010.02.001

Hall, R. J., Skakun, R. S., Arsenault, E. J., \& Case, B. S. (2006). Modeling forest stand structure attributes using Landsat ETM + data: Application to mapping of aboveground biomass and stand volume, 225, 378-390. http://doi.org/10.1016/j.foreco.2006.01.014

Jibrin, A., Zubairu, S. M., \& Kaura, S. J. (2014). Carbon Sequestration Potential of Kpashimi Forest Reserve, Niger State, Nigeria, 2(1), 149-163.

Labrecque, S., Fournier, R. A., Luther, J. E., \& Piercey, D. (2006). A comparison of four methods to map biomass from Landsat-TM and inventory data in western Newfoundland, 226, 129-144. http://doi.org/10.1016/j.foreco.2006.01.030

Lal, R., J.M. Kimble, R.F. Follett and C.V. Cole (1999). The Potential of U.S. Cropland to Sequester Carbon and Mitigate the Greenhouse Effect. Lewis Publishers.

Lu, D., Chen, Q., Wang, G., Moran, E., Batistella, M., Zhang, M., Saah, D. (2012). Aboveground Forest Biomass Estimation with Landsat and LiDAR Data and Uncertainty Analysis of the Estimates. International Journal of Forestry Research, 2012(1), 16. http://doi.org/10.1155/2012/436537

MacDicken, K.G. 1997. A guide to monitoring carbon storage in forestry and agroforestry projects. USA, Winrock International Institute for Agricultural Development.

Manual of Observatory (2016). Trends in Atmospheric Carbon Dioxide. Retrieved from: http://www.esrl.noaa.gov/gmd/ccgg/trends/global.html Accessed 11 March 2016.

Momodu, A. S., Siyanbola, W. O., Pelemo, D. A., Obioh, I. B., \& Adesina, F. A. (2011). Carbon flow pattern in the forest zones of Nigeria as influenced by land use change. African Journal of Environmental Science and Technology, 5(9), 700-709. http://doi.org/10.5897/AJEST11.050

NASA (2016). Goddard Earth Sciences Data and Information Services Centre. Retrieved from: http://disc.sci.gsfc.nasa.gov/OCO-2. Accessed 11 March 2016.

Ndor, E. and Iorkua, S. A. (2013). Effect of Agricultural Land Use On Carbon Sequestration And Chemical Properties. Global Journal of Biodiversity Science and Management, 3(1), 68-72. 
Omodanisi, E. O. (2011). The Effect of Oil Pipeline Vandalization on the Mangrove Vegetation: A Case Study. International Journal of Ecology \& Development. Vol. 19 No. S11, pp. 76-85.

Onyekwelu J.C., Mosandl R. and Stimm, B. (2008). "Tree species diversity and soil status of primary and degraded tropical rainforest ecosystems in South-Western Nigeria". Journal of Tropical Forest Science Vol. 20 No. 3, pp. 193-204.

Onyekwelu, J.C., Mosandl, R., and Stimm, B. (2006). Productivity, site evaluation and state of nutrition of Gmelina arborea plantations in Oluwa and Omo forest reserves, Nigeria. Forest Ecology and Management. 229(1-3): p. 214-227.

Oseni, O. A., Ekperigin, M. M., Akindahunsi, A. A., \& Oboh, G. (2007). Studies of physiochemical and microbial properties of soils from rainforest and plantation in Ondo state, Nigeria. African Journal of Agricultural Research, 2(11), 605-609.

Osunade, M.A.A. (1991). "Agricultural change by supplanting process in a traditional farming System". International Journal of Ecology and Environmental Sciences, Vol. 17, pp. 201-209.

Popo-Ola, F. S., Aiyeloja, A. A. Adedeji, G. A. (2012). Sustaning Carbon Sink Potentials in Tropical Forest. Journal of Agriculture and Social Research, 12(1), 64-73.

Prentice, C., and Co-authors, 2001: The carbon cycle and atmospheric carbon dioxide. Climate Change 2001: The Scientific Basis, J. Houghton et al., Eds., Cambridge University Press, 183-237.

Sato, J. H., Figueiredo, C. C. De, Marchão, R. L., Madari, B. E., \& Celino, L. E. (2014). Methods of soil organic carbon determination in Brazilian savannah soils. Scientia Agricola, 71(4), 302-308.

SCBD, Secretariat of the Convention on Biological Diversity (2010). Forest Biodiversity-Earth's Living Treasure. Montreal, 48 pages.

Schumacher, B. A. (2002). Methods for the Determination of Total Organic Carbon in Soils and Sediments. Ecological Risk Assessment Support Center (Vol. 32).

Udoakpan, U. I. (2013). Assessment of Some Physical Properties of Pinus Caribeae (Morlet) in a Four Different Age Plantation in Oluwa Forest Reserve, Nigeria. ARPN Journal of Science and Technology, 3(6), 662-668.

USAID. (2008). Nigerian Biodiversity and Tropical Forestry. Education and Training, (June).

Zhu, X. (2014). Generating High-Quality Landsat Time-Seris and Its Applications in Forest Studies. A Dissertation submitted to The Ohio State University. 